\title{
Central Santa Catarina coastal dunefields chronology and their relation to relative sea level and climatic changes
}

\author{
Cronologia dos campos de dunas da costa central catarinense e a \\ influência do nível relativo do mar e das mudanças climáticas
}

\author{
Vinícius Ribau Mendes ${ }^{1 *}$, Paulo César Fonseca Giannini², \\ Carlos Conforti Ferreira Guedes ${ }^{3}$, Regina DeWitt ${ }^{4}$, Helena Asmar de Abreu Andrade ${ }^{1}$
}

\begin{abstract}
During the past decades, there have been contrarian explanations for the formation and stabilization of coastal dunefields: while many authors believe the dunes formation would be enhanced by falling sea level, others argue that a rising or stable sea level context would be favorable. For Brazilian coastal dunefields, the second hypothesis seems to be more consistent with the luminescence ages found so far; however, most of these data were obtained without using the SAR protocol. Another point of concern is the role of climate change in the aeolian system, which is still not very clear. The aim of this paper is to try to clarify these two questions. To this end, five coastal dunefields were selected in central Santa Catarina coast. The remote sensing and dating results allowed the discrimination and mapping of at least four aeolian generations. Their age distribution in relation to the global curve of relative sea level variation during the Late Pleistocene allows us to suggest that the formation of Aeolian dunefields in the coastal context is supported by stable relative sea level. However, relative sea level is not the only determinant for the formation and preservation of the aeolian coastal dunes. Evidences of climatic control indicate that the initiation of dunefields would be favored by periods of less humidity while their stabilization would occur preferably during the periods of rain intensification, connected to monsoon activity.
\end{abstract}

KEYWORDS: OSL-SAR dating; Dune stabilization; Aeolian generations.
RESUMO: A formação e estabilização de campos de dunas costeiros têm sido explicadas de maneiras contrárias ao longo das últimas décadas: enquanto alguns autores acreditam que a formaçāo das dunas seria favorecida pelo nivel do mar descendente, outros autores defendem que o contexto de nivel do mar estável seria mais favorável à sua formação. No caso dos campos de dunas costeiros do Brasil, a segunda hipótese parece ser mais consistente com as idades de luminescência obtidas até o momento; no entanto, a maior parte desses dados foi obtida sem o uso do protocolo SAR (Single Aliquot Regenerative dose). Outra questäo em aberto seria qual o papel exercido pelas mudanças climáticas no sistema eólico. Este artigo tenta clarear essas duas questöes, e para essa finalidade foram escolhidos cinco campos de dunas na costa central catarinense. Os dados de sensoriamento remoto e das dataçóes absolutas permitem a discriminação e mapeamento de pelo menos quatro geraçôes eólicas. A distribuição das idades encontradas em relação à curva global de variação do nivel do mar permite sugerir que a formação dos campos de dunas estaria relacionada com nivel do mar estável. Contudo, o nivel relativo do mar não é a única variável determinante no sistema eólico costeiro. Foram encontradas evidências de controle climático, e a formação das dunas estaria ligada a periodos de menor precipitaçáo enquanto sua estabilizaçáo ocorreria em momentos de intensificação das chuvas, ocasionados por aumento nas atividades das monçôes.

PALAVRAS-CHAVE: Dataçóes LOE-SAR; Estabilização de dunas; Geraçôes eólicas.

\footnotetext{
${ }^{1}$ Post-graduation Program in Geochemistry and Geotectonic, Geoscience Institute, Universidade de São Paulo - USP, São Paulo (SP), Brasil. E-mail: viniciusr@usp.br; helenahabs@gmail.com

²Environmental and Sedimentary Geology Department, Geoscience Institute, Universidade de São Paulo - USP, São Paulo (SP), Brasil. E-mail: pcgianni@usp.br ${ }^{3}$ Department of Marine Sciences, Marine Institute, Universidade Federal de São Paulo - UNIFESP, Campus Baixada Santista, Unidade II, Santos (SP), Brasil. E-mail:ccfguedes@gmail.com

${ }^{4}$ Department of Physics, East Carolina University, USA. E-mail: dewittr@ecu.edu

*Corresponding author.

Manuscript ID: 30143. Received: 07/30/2014. Approved: 01/14/2015.
} 


\section{INTRODUCTION}

Santa Catarina central coast, between Ouvidor and Florianópolis, has five active dunefields with 1 to $3 \mathrm{~km}$ length (Fig. 1). Some of these dunefields were previously studied with emphasis on the geomorphology and sedimentology of their deposits (Bigarella 1975, Bigarella et al. 2005, Miot da Silva 2006, Hesp et al. 2009, Dillenburg et al. 2014). No work has been published for this region, focussing on the chronology of dunefield evolution throughout the late Quaternary, except for attempts by Hesp et al. (2009) to distinguish aeolian Holocene pulses in Pinheira strandplain. This kind of focus is becoming more common in both national (Giannini \& Suguio 1994, Barbosa 1997, Dillenburg et al. 2006, Giannini et al. 2007, Barreto et al. 2002, 2004, Martinho \& Giannini 2001, Claudino-Sales \& Peulvast 2002, Sawakuchi et al. 2008) and international research (Pye 1983, Endo 1986, Short 1988, Stokes et al. 1997, Loope \& Arbogast 2000, Lees 2006), in particular during the last two decades. The main reasons for the renewed interest in this subject are the possible implications of the different generations of aeolian dunefields and their time-space distribution for the study of sedimentary supply, climate and relative sea level (RSL) behavior.

Similar studies were performed in the region of JaguarunaImbituba (Giannini 1993, Sawakuchi 2003, Giannini et al. 2007), to the south of the present study area. The results of those studies allowed recognizing at least four dunefield generations. Morphostratigraphic interpretations, reinforced by the results of luminescence dating in this region, led Giannini et al. (2007) to suggest a model for the formation and preferential preservation of coastal aeolian deposits in terminal transgressive and high sea system tracts. The average ages obtained by luminescence in Santa Catarina centre-south (Giannini et al. 2007) and Rio Grande do Norte (Barreto et al. 2004) are in reasonable agreement. These results seem to strengthen the hypothesis of inter-regional correlation between the generations of Aeolian dunefields on the Brazilian coast (Giannini 2007), which would be sea level controlled.

However, one question that arises from this hypothesis of dunefield formation deserves some refinement or revision: the two youngest aeolian generations found in Santa Catarina centre-south, in Rio Grande do Norte and in other Brazilian coastal sectors were formed during the last millennia, after the Holocene maximum RSL (around $5.5 \mathrm{ky} \mathrm{BP}$ ). Thus, factors that control the coastal dunefield dynamics are still not fully understood, since one changes from the tens of thousandsof yearstimescale (in which the influence of RSL variation of more than $100 \mathrm{~m}$ seems relevant) to the millennial or decadal scale (in which the RSL variation accounts only for less than $3 \mathrm{~m}$ ). Two questions were addressed in the present study: Are the climatic oscillations in southern South America (Cruz et al. 2006, 2007, 2009, Wang et al. 2006, Haylock et al. 2006), which are connected to sub-Milankovitch events, such as the Heinrich events (Heinrich 1988) and the Little Ice Age (LIA), the main factors controlling coastal dunefield dynamics on a short timescale? Does the beginning and stabilization of dunefields mean a defined climate throughout the late Holocene?

To address these questions, the Santa Catarina central coast was chosen for two reasons. Firstly, because the area is immediately adjacent in the north to the region between Imbituba and Jaguaruna, which has been previously subject to the above mentioned studies about stratigraphy and chronology of coastal dunefields (Giannini et al. 2007). Secondly, because it covers precisely the limit between the dunefields migrating to SW (Fig. 1), that are predominant from Pinheira toward south, and the dunes and blowouts migrating to $\mathrm{N}$ to NW, that are found from Pinheira to north in south-southeast Brazil, especially at Santa Catarina island (Hesp et al. 2007) and São Francisco do Sul (Zular 2011), in Santa Catarina State, and at Ilha Comprida (Sawakuchi et al. 2008, Guedes et al. 2011) in São Paulo State.

\section{REGIONAL SETTING}

\section{Geologic and geomorphologic features}

The study area is located in the second southernmost physiographic-structural sector of the Brazilian coast (Giannini 2007), which stretches with a general NNE orientation from Imbituba $\left(28^{\circ} 15^{\prime} \mathrm{S}\right)$ to Itajaí-Joinville (26ำ $\left.15^{\prime} \mathrm{S}\right)$. In comparison with its northern and southern neighbors, this coastal sector is more interrupted by headlands and with a narrower and steeper inner continental shelf $\left(0.07\right.$ to $\left.0.26^{\circ}\right)$.

According to Martin et al. (1988), the study area is a coastal plain formed by four main deposit types: two marine sandy terraces, with Pleistocene and Holocene ages; coastal dunes, mainly from the Holocene; and clayey or silty sands, also from the Holocene. The Pleistocene terraces, related to the high RSL 120,000 yr BP, are preserved in the innermost portions of the coastal plain, where, according to those authors, they could reach about $9.5 \mathrm{~m}$ high. The Holocene sandy terraces occur along the outer edge of the Pleistocene terraces, sometimes separated from them by low lands and marshlands (Martin et al. 1988) related to partially filled lagoons and estuaries. According to the authors, they can reach $4 \mathrm{~m}$ high. The clayey and silty sands are mostly found at south from Pinheira in small bays and lowlands around the estuarine and lagoon systems. In Pinheira strandplain, 

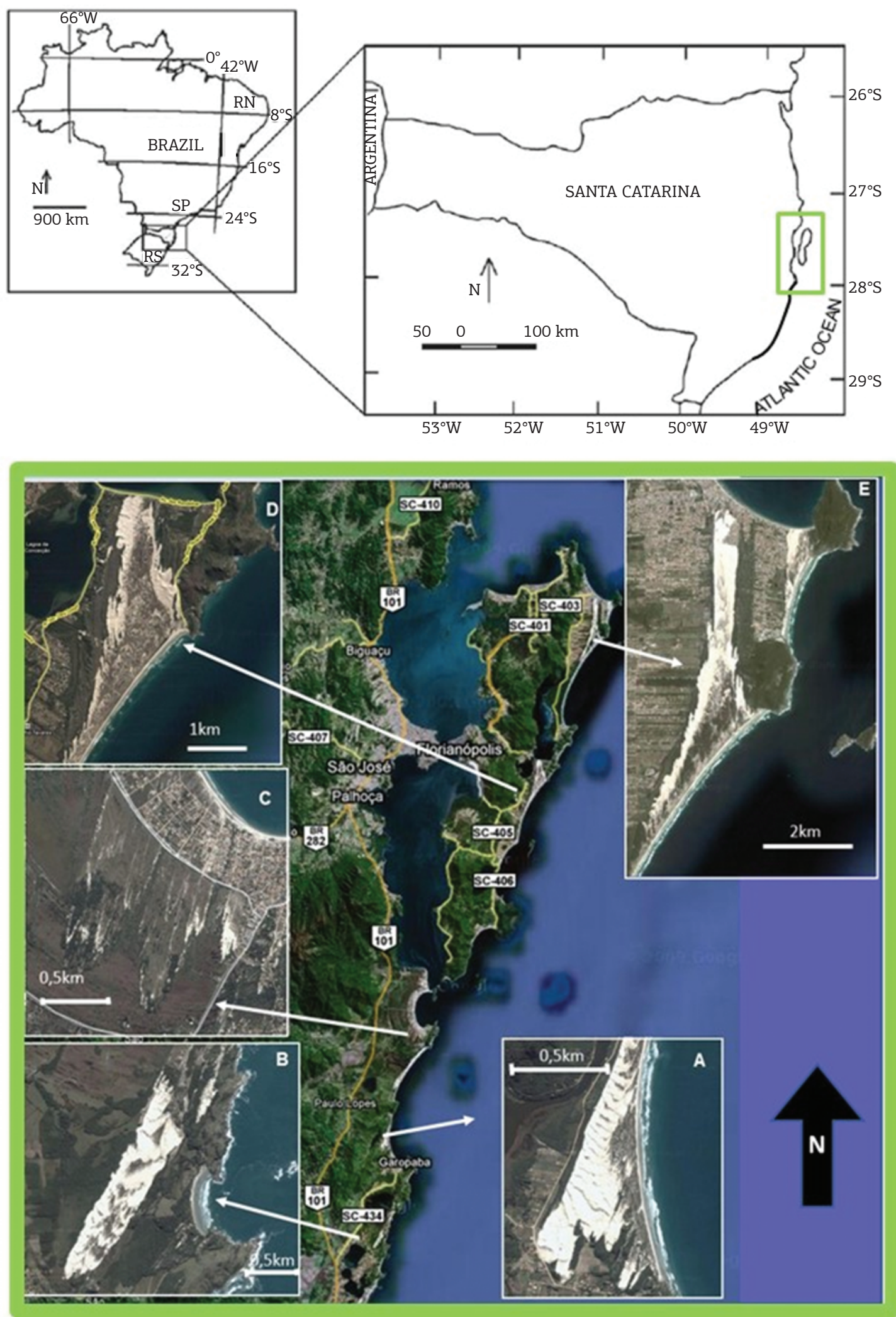

Images taken from Google Earth ${ }^{\star}$. Other states cited in this article: RN = Rio Grande do Norte; SP = São Paulo; RS = Rio Grande do Sul.

Figure 1. Location of the study area. From south to north, it includes Five beach (dunefields) systems (A) BarraOuvidor (Ouvidor); (B) Siriú - Morro da Antena (Garopaba); (C) Pinheira - Rio da Madre (Pinheira); (D) CampecheConceição (Joaquina); and (E) Moçambique - Ingleses (Ingleses). 
the Holocene terrace clearly corresponds to a strandplain, as evidenced by the sets of foredune ridges (Hesp et al. 2009, Barboza et al. 2009, Hein et al. 2013, Dillenburg et al. 2014, Hein et al. 2014).

Coastal dunefields become well developed from the studied area to the south coast of Brazil (Bigarella 1975). Based on stratigraphic, geomorphologic, mineralogical and textural features, Giannini $(1993,2002)$ and Giannini et al. (2005) could recognize at least four aeolian dune generations in south Santa Catarina State. Giannini et al. (2007) grouped them in two sequences, indicating a major RSL influence in their formation and, therefore, a regional expression. The generation 1 (G1) was formed before the last Pleistocene highstand (120 ka). The generation 2 (G2) comprises dunefields formed before the Holocene highstand, while generations 3 and 4 (G3 and G4) were formed after this highstand. The difference between these last two generations is that G4 is still active at present.

Santa Catarina coast has more than 30 dated indicators of RSL positions during the Holocene, obtained in vermetid (encrusting marine gastropods) remains (Angulo et al. 2006). These data indicate a maximum RSL of $2.1 \pm 1.0 \mathrm{~m}$ higher than the present RSL, reached 5916-5597 ${ }^{14} \mathrm{C}$ cal years before present (BP) (Angulo et al. 2006).

\section{Climate and oceanography}

According to Cruz et al. $(2006,2009)$ and Garreaud et al. (2009), there are two important sources for the moisture involved in southern South America precipitation. The first one, named South American Monsoon System (SAMS), is related to the Intertropical Convergence Zone (ITCZ) and the South Atlantic Convergence Zone (SACZ), and is intensified during austral summer. It has major importance for the rainfall in most of South America, being responsible for approximately 60\% of Santa Catarina state precipitation (Cruz et al. 2007). The second source of moisture, called frontal system (cold fronts), is responsible for the winter rains and reaches the Brazilian south and southeast coast. These climatic phenomena result from migratory cyclones along the subtropical Atlantic coast (Vera et al. 2002). Both climatic systems affect the wind patterns (Fig. 2): the stronger $S$ winds are associated with the cold front system, as the intensification of SACZ pushes the $\mathrm{N}$ wind offshore.

Imbituba's harbor tidal board marks the mean astronomical tide oscillation at $0.6 \mathrm{~m}$ within a semi-diurnal regime (Giannini 1993). Based on the records (2002-2003) of the Arvoredo Island, located $35 \mathrm{~km}$ offshore from the island of Santa Catarina, Hesp et al. (2009) identified two trends in the significant wave height and direction distribution of swells arriving at the central coast of Santa Catarina. The first trend, most common and related to large-scale climatic phenomena, is represented by swells from $S$ (17), with an average period of $12 \mathrm{~s}$ and height of 1.0 to $1.5 \mathrm{~m}$. The second one is related to air masses generated locally and translates into waves coming from $\mathrm{ENE}\left(70^{\circ}\right.$ azimuth), with a $7 \mathrm{~s}$ mean period and up to $1.0 \mathrm{~m}$ height.

Geomorphological, granulometric and mineralogical evidences, applied in different beaches in the sector between Laguna and Imbituba (Giannini 1993, 2002, 2007, Martinho et al. 2006), indicate predominance of net longshore sediment transport from S-SW to N-NE.

\section{MATERIALS AND METHODS}

\section{Remote sensing}

Aerial photographs and satellite imagery were used to identify aeolian morphologic elements and to map morphostratigraphic units (possible generations of aeolian deposits). The historical series of aerial photographs includes the years 1938 (available only for the Ingleses, Joaquina and Pinheira dunefields), 1957 and 1978. These photos were georeferenced and compared with each other and with satellite images (2001 to 2009) from the Google Earth software.

\section{OSL dating}

The OSL method was applied to quartz grains from 13 sand samples, 11 of which are aeolian paleodunes, and 2 are marine constructive terraces. These samples were selected among 119 samples collected during the fieldwork. The sample preparation followed the standard coarse-grain quartz extraction procedure, including treatment with $\mathrm{HCl}$ and $\mathrm{H}_{2} \mathrm{O}_{2}$, etching with HF, and density separation, all under red light.

The OSL-SAR procedure described by Murray and Wintle (2000) and Wintle and Murray (2006) was applied to quartz grains of $120-150 \mu \mathrm{m}$ diameter, which is the most accepted procedure for the determination of the radiation dose accumulated in quartz grains. The luminescence signals were measured with a Risø DA-15 TL/OSL system at the Radiation Dosimetry Lab at Oklahoma State University - USA. The ${ }^{90} \mathrm{Sr} /{ }^{90} \mathrm{Y}$ beta source attached to this equipment provided a dose rate of $93.2 \pm 4.1 \mathrm{mGy} / \mathrm{s}$. The heating rate used was $5^{\circ} \mathrm{C} / \mathrm{s}$, and all aliquots were prepared with the same volume ( $\sim 400$ grains).

The annual radiation dose rate was measured with a high purity germanium detector (HPGe), at the Physics Institute of Universidade de São Paulo. The contribution of the cosmic radiation to the annual dose was calculated according to Barbouti and Rasin (1983) and Prescott and Stephan (1982), using latitude, longitude, altitude and collection depth, as well as the density of each sample. Total error of the annual dose was estimated according to the Gaussian law of error propagation. 


\section{RESULTS}

\section{OSL dating}

Out of the 11 OSL ages obtained from aeolian samples, five belong to G3, four to G2 and two to G1. Out of the two OSL ages from marine terraces, one is Pleistocene (IN-TP-06) and the other is Holocene (PI-TH-49, Tab. 1).

The G1 samples present two ages that overlap within error limits, with a range between 350 to $240 \mathrm{ky}$. The four ages present in G2 appear distributed over three age ranges. The oldest one comprises one sample and is located around $50 \mathrm{ky}$. The second range comprises two samples, around $21 \mathrm{ky}$, and the last range has one sample of about $10 \mathrm{ky}$.
The five dates for G3 are distributed over two temporal ranges, the first and oldest one is $5.5 \pm 0.8 \mathrm{ky}$. The second temporal range comprises four samples and is almost continuous, from about 1,900 to 600 years. There is a hiatus between these ranges at around $2.5 \mathrm{ky}$.

\section{Distribution of the Quaternary sedimentary units}

The Quaternary aeolian sedimentation of Santa Catarina central coast can be divided into four generations (Figs. 3 to 7), matching the ones observed by Giannini et al. (2007).

The oldest generation G1 occurs associated with crystalline rock hills (Figs. 3, 4 and 6). It appears dissected by drainages so the aeolian features are not recognizable

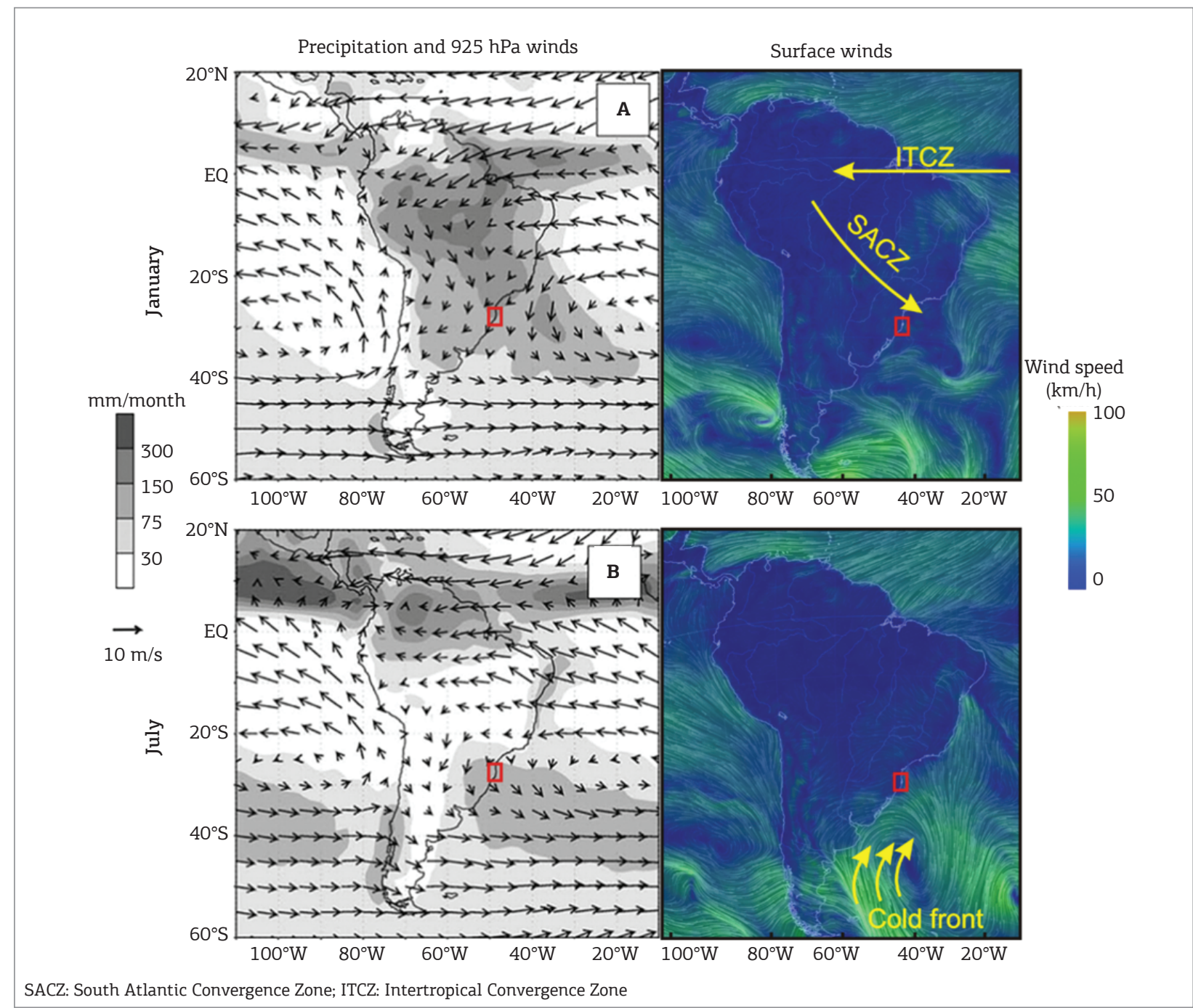

Figure 2. Precipitation and $925 \mathrm{hPa}$ wind map (left) and surface winds (right) for South America. Squares show the study area. During austral summer, (A) the SACZ is intensified and pushes the northern winds offshore; on the other hand, during austral winter, (B) the cold fronts and the associated southern winds (left maps modified from Garreaud et al. 2009; right images modified from http://earth.nullschool.net). 
neither in satellite images and aerial photos, nor in the field. In the Ingleses dunefield area (Fig. 3) and at the south portion of Garopaba region (Fig. 6), the identification of G1 was mostly based on morphologic criteria (absence of depositional forms) as suggested by Giannini et al. (2007). In the Joaquina dunefield area (Fig. 4) and in the north portion of Garopaba (Fig. 6), G1 was also indicated by OSL dates. The new information found in the present study, compared to what had been described so far for this generation, is the existence of ages older than the last Pleistocene highstand (about $120 \mathrm{ky}$ ). These ages (274 \pm 25 and $318 \pm 34$ ky, respectively Fig. 4 and 6) are also the oldest found for Quaternary sedimentary coastal deposits in all of the south and southeast Brazilian coast, at least for published OSL-SAR dating results.

G2 occurs as softly wavy terrain (undulations about $3 \mathrm{~m}$ high and $150 \mathrm{~m}$ long), with a medium altitude around $25 \mathrm{~m}$, covering the Pleistocene terraces from $10 \mathrm{~m}$ high, attributed to the high RSL of $120 \mathrm{ky} \mathrm{BP.} \mathrm{As} \mathrm{far} \mathrm{as} \mathrm{area} \mathrm{is}$ concerned, it is the most representative aeolian generation for the region and represents G3 and G4 substrate in the Ingleses (Fig. 3), Joaquina (Fig. 4) and Garopaba (Fig. 6) dunefields, although aeolian features cannot be recognized in the morphology there. However, it was possible to identify sedimentary structures typical of wind deposition in outcrops, i.e., trough cross stratifications, in sets up to $3 \mathrm{~m}$ thick (Fig. 8). The festoon cross-stratification pattern, found in the section WNW-ESE, is compatible with the migration direction of the barchanoid aeolian chains, which is SSW_NNE in this region. Eighteen measurements of cross stratification confirm the dominance of an $\mathrm{N} 17^{\circ}$ direction paleowind. Waved terrains with similar characteristics, and with possible tenuous parabolic shapes in aerial photos, were already described in the regions of Imbituba and Jaguaruna, center-south littoral of Santa Catarina, by Giannini (1993), who classified them as G2.

G3 has a well preserved aeolian morphology and it is found in the surroundings of active dunefields (G4) as precipitation ridges with a parallel orientation to the present dunefield (Fig. 8). An exception is in Pinheira, where different G3 dunefield pulses appear dispersed on the south portion of Holocene strandplain (Fig. 5). Stratigraphically, G3 occurs over the pre-Cenozoic crystalline basement, above the Pleistocene marine terrace and, to a greater extension, above the sandy terrain of wavy surface identified as G2.

The active dunefields (G4) show a spatial distribution related to the G3 deposits, which are sometimes partially overlapped by them. G4 appears surrounded almost exclusively by G3 and suffers a stabilization process by vegetation growth in the deflation zone, and by the consequent reduction of sedimentary supply for the more distal wind features, such as depositional frontal lobes and precipitation ridges (Mendes \& Giannini 2015).

Table 1. Relation of the dated samples with the corresponding depositional facies, ages, associated error and sedimentary units

\begin{tabular}{l|c|c|c|c|c}
\hline \multicolumn{1}{l}{$\begin{array}{l}\text { Sample } \\
\text { code }\end{array}$} & \multicolumn{1}{c}{ Facies } & Age (ky) & Sedimentary unit & Dose (mGy) & $\begin{array}{c}\text { Total dose rate } \\
\text { (mGy/year) }\end{array}$ \\
\hline PI-G3-56 & Depositional lobe & $0.59 \pm 0.06$ & G3 & $330 \pm 14$ & $0.560 \pm 0.051$ \\
\hline OU-G3-103 & Depositional lobe & $0.9 \pm 0.1$ & G3 & $554 \pm 24$ & $0.589 \pm 0.056$ \\
\hline PI-G3-54 & Depositional lobe & $1.2 \pm 0.1$ & G3 & $840 \pm 36$ & $0.683 \pm 0.056$ \\
\hline JO-G3-40 & Precipitation ridge & $1.8 \pm 0.2$ & G3 & $607 \pm 26$ & $0.339 \pm 0.037$ \\
\hline PI-G3-53 & Depositional lobe & $5.5 \pm 0.8$ & G3 & $1,387 \pm 59$ & $0.252 \pm 0.037$ \\
\hline JO-G2-31 & Undetermined & $10.4 \pm 1.1$ & G2 & $5,210 \pm 220$ & $0.501 \pm 0.048$ \\
\hline IN-G2-07 & Barchanoid chain & $19.0 \pm 2.1$ & G2 & $6,147 \pm 264$ & $0.327 \pm 0.033$ \\
\hline PI-G2-74 & Depositional lobe? & $23.5 \pm 2.0$ & G2 & $18,120 \pm 782$ & $0.773 \pm 0.057$ \\
\hline IN-G2-09 & Wind ramp? & $50.5 \pm 4.4$ & G2 & $60,200 \pm 2,700$ & $1.191 \pm 0.089$ \\
\hline PM-G1-21 & Wind ramp? & $274 \pm 25$ & G1 & $208,700 \pm 8,600$ & $0.761 \pm 0.063$ \\
\hline GP-G1-90 & Depositional lobe? & $318 \pm 34$ & G1 & $149,500 \pm 6,100$ & $0.471 \pm 0.047$ \\
\hline IN-TP-06 & Foreshore? & $123 \pm 11$ & Pleistocene terrace & $137,790 \pm 5,894$ & $1.120 \pm 0.084$ \\
\hline PI-TH-49 & Foredune? & $1.5 \pm 0.1$ & Holocene & $893 \pm 37$ & $0.614 \pm 0.057$ \\
\hline
\end{tabular}




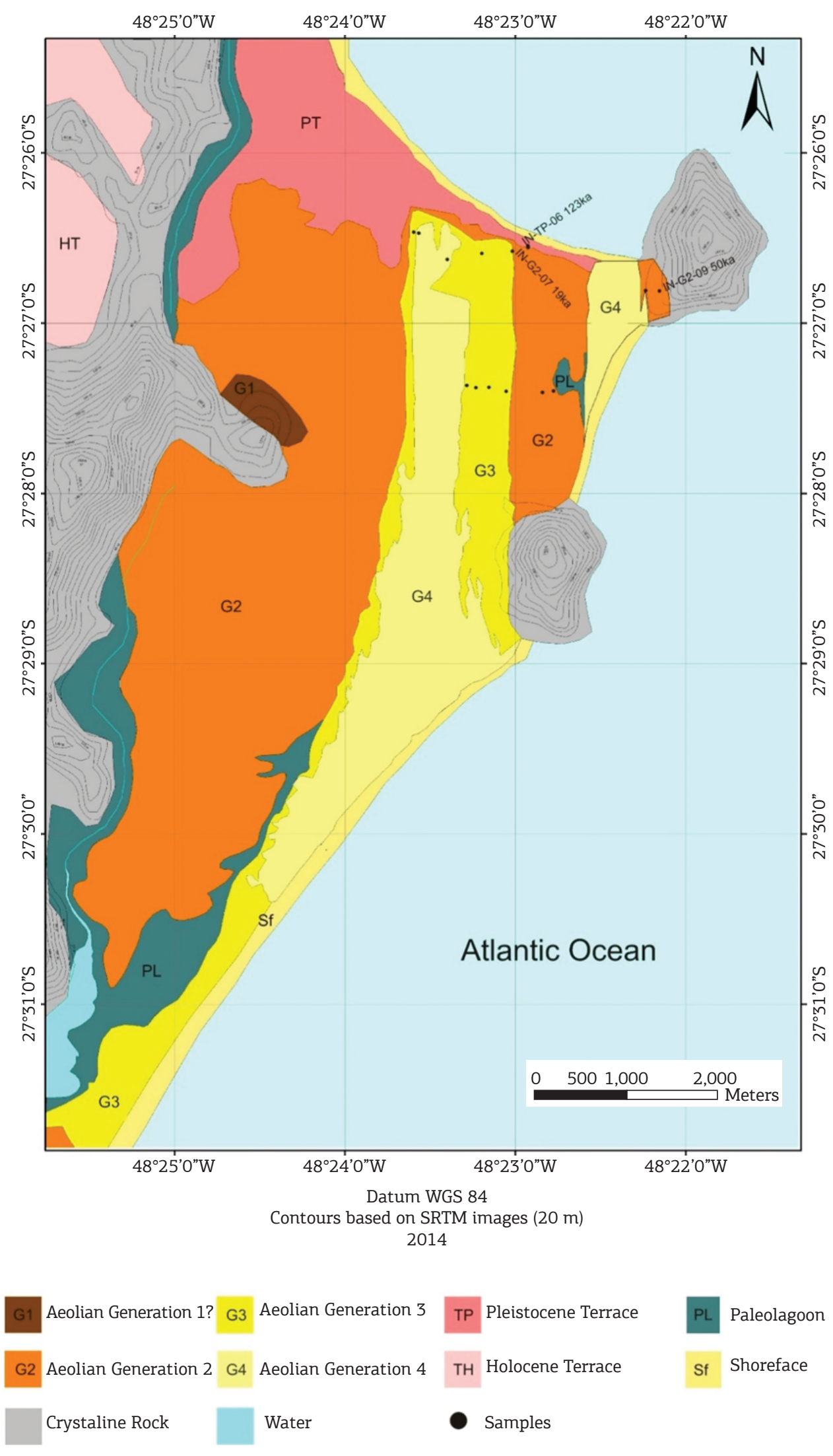

Figure 3. Distribution of the Quaternary sedimentary units for the Ingleses dunefield area. The dated samples are labeled with the sample name and the OSL age. 


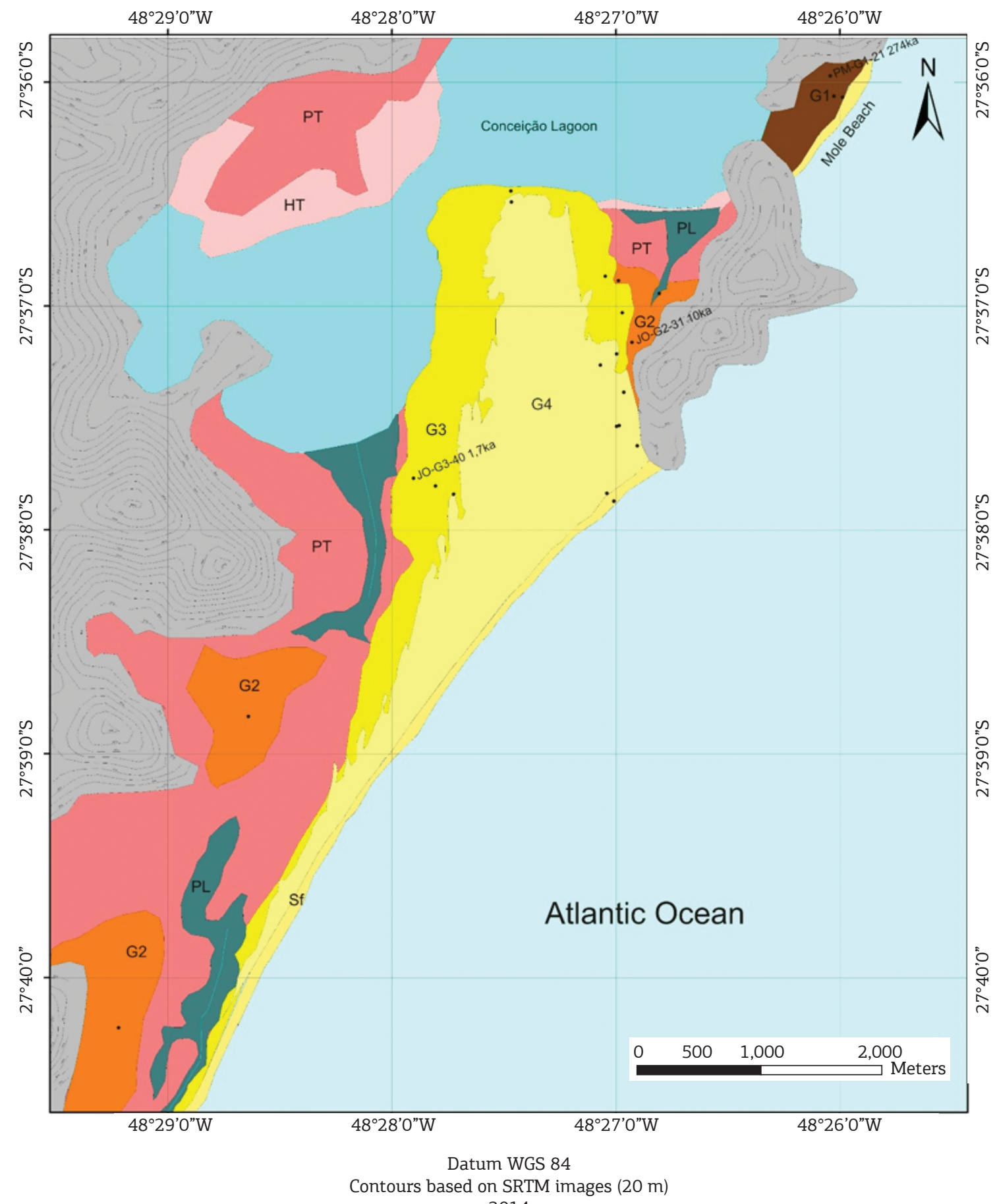

2014

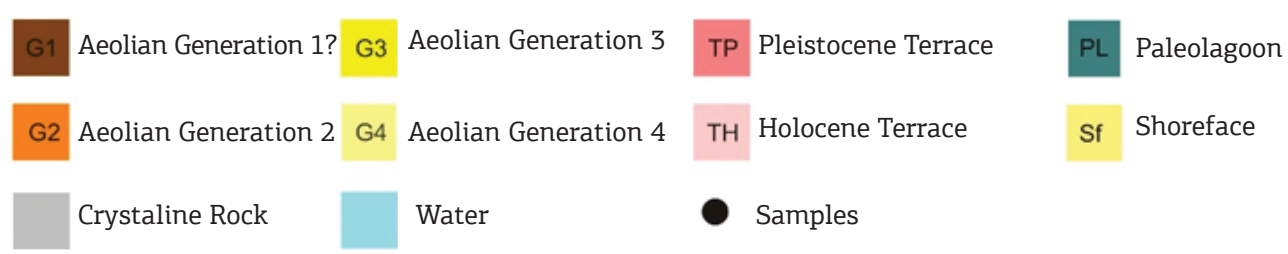

Figure 4. Distribution of the Quaternary sedimentary units for the Joaquina dunefield area. The dated samples are labeled with the sample name and the OSL age. 


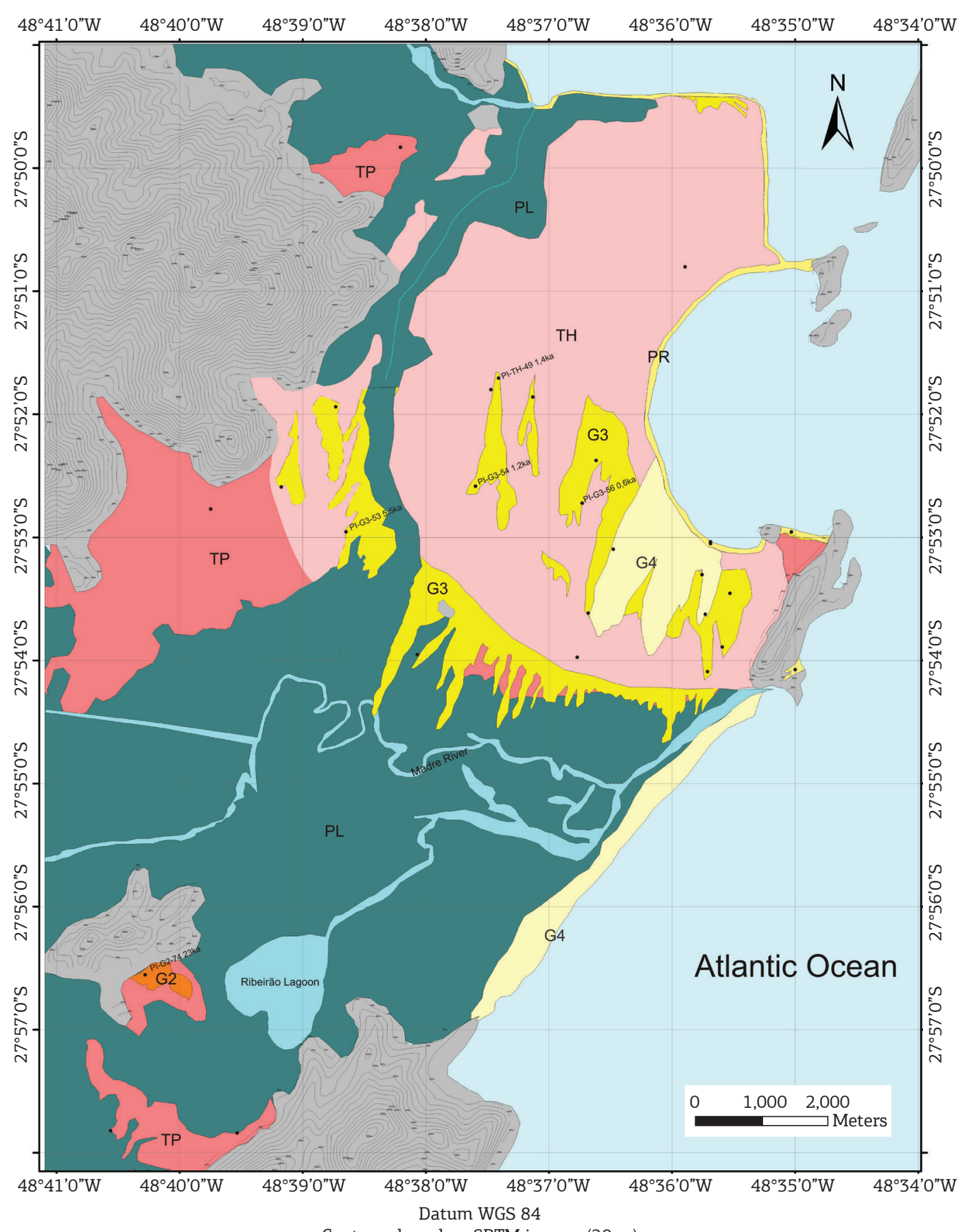

Contours based on SRTM images (20 m)

2014

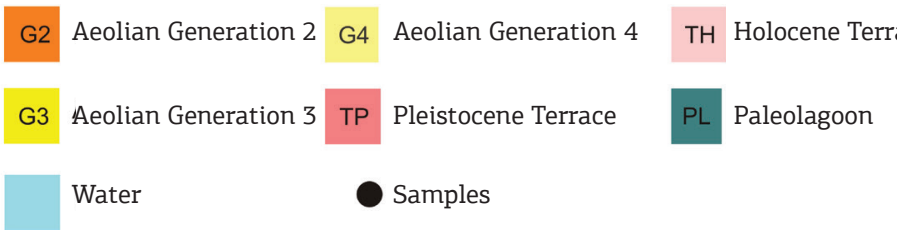

Sf Shoreface

Figure 5. Distribution of the Quaternary sedimentary units for the Pinheira strandplain region. The dated samples are labeled with the sample name and the OSL age. 


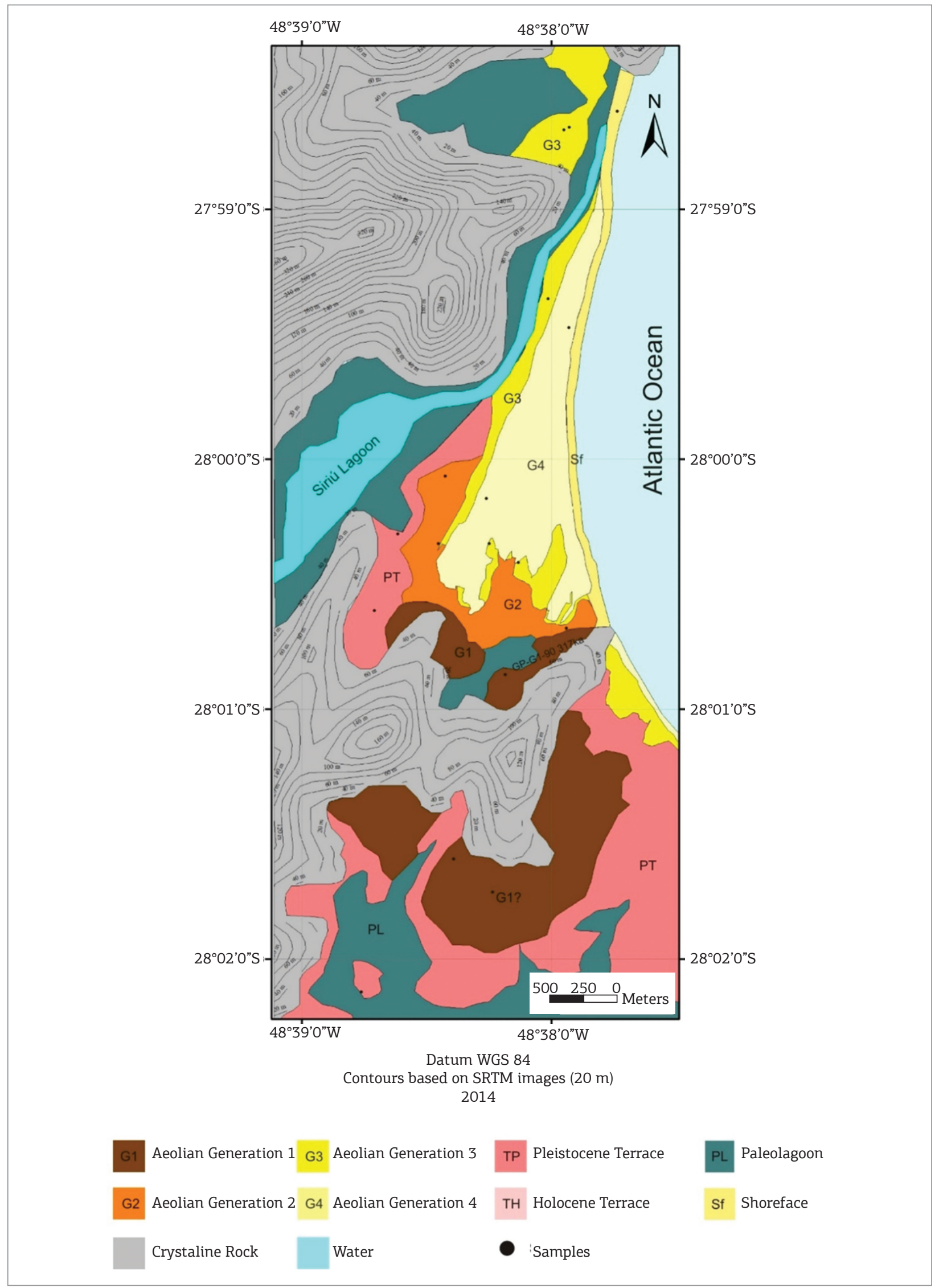

Figure 6. Distribution of the Quaternary sedimentary units for the Garopaba dunefield area. The dated samples are labeled with the sample name and the OSL age. 
The paleolagoon corresponds to the area where the Pleistocene terrace and its overlapping G2 paleodunes have been drowned (and subsequently silted) since the Holocene maximum inundation. It appears to have formed preferably in locations with incised drainages (incised valleys) under a lower than present base level, as exemplified by the extended occurrence of its deposits throughout the contact between the crystalline rocks and the Pleistocene terrace and G2 sedimentary deposits (Fig. 3).

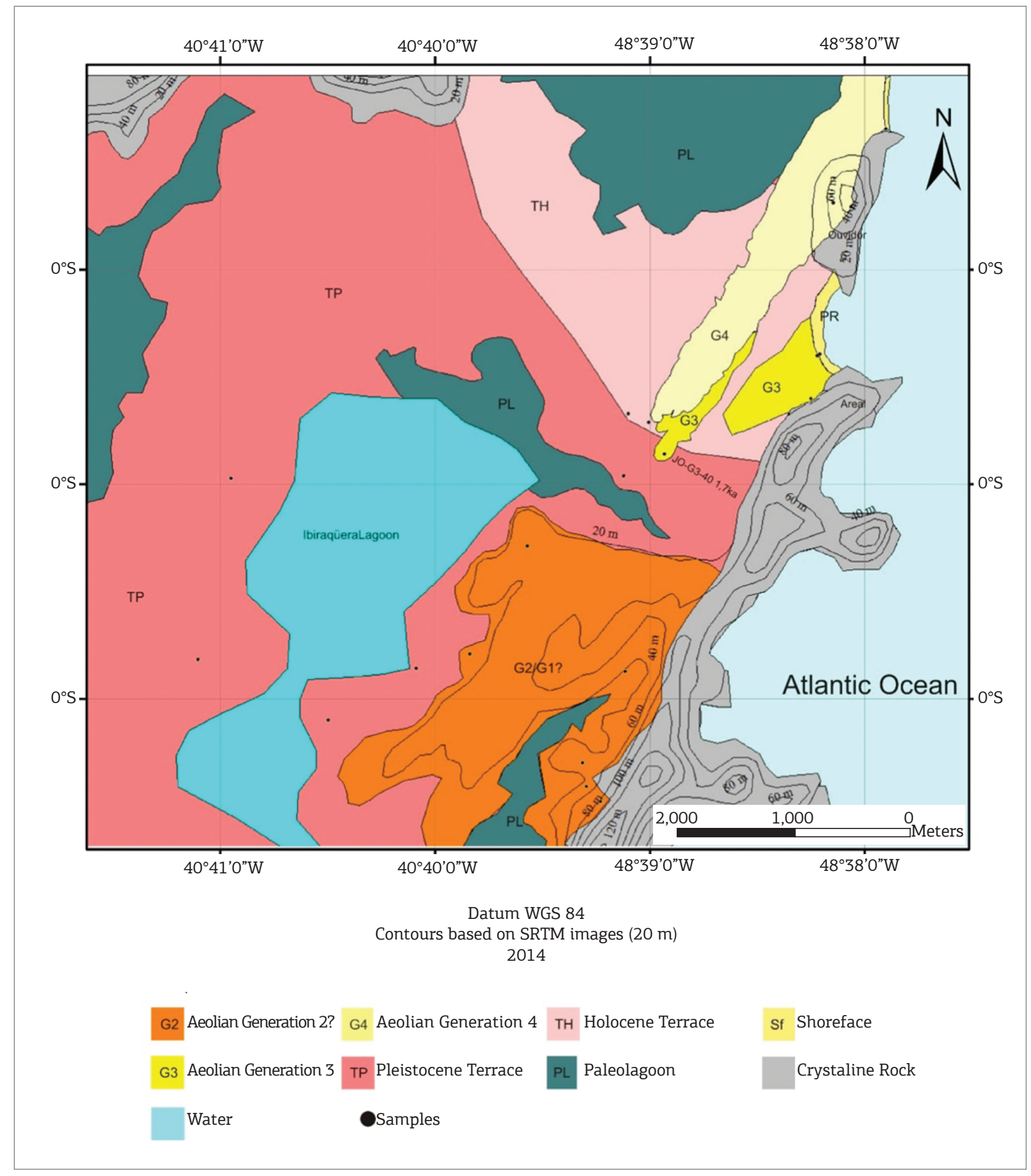

Figure 7. Distribution of the Quaternary sedimentary units for the Ouvidor dunefield area. The dated samples are labeled with the sample name and the OSL age. 


\section{DISCUSSIONS}

\section{Geological significance of OSL ages in aeolian deposits}

In theory, the OSL age represents the time of sediment burial and, if obtained from the most distal depositional lobe of the dunefield, it provides a good estimate for the stabilization of the aeolian system. Nevertheless, depending on the uncertainty of the OSL method and the duration ("lifetime") of the dunefield active period, there is a probability that the time frame obtained with OSL does not only include the stabilization ("death") of the dunefield but also its initiation ("birth"). The greater the sand volume of the dunefield, the longer is its active period. Therefore, in relatively small coastal dunefields as the ones studied here, the life-time of the aeolian system tends to be shorter than the precision of the OSL dating method (like few hundred years), which for our samples is close to $10 \%$, so the dunefield initiation can be included in the age as well as the stabilization. This should be viewed therefore as a general premise to the two following topics of discussion.

\section{Age distribution in relation to RSL variations}

The aim was to characterize the RSL behavior during the periods that coincide with the obtained OSL ages of the aeolian dunes. Five situations were distinguished, using the available OSL results (Fig. 9):

1. strongly ascending RSL;

2. strongly declining RSL;

3. stable RSL with gentle decrease;

4. stable high RSL linked to tendency inversion (positive peak of the variation curve); and

5. stable low RSL, linked to tendency inversion (negative peak of the variation curve).

From the nine available youngest OSL ages, and considering the respective error margins, the distribution of the ages is as follows: one in the case 1, one in the case 2, five in the case 3 , one in the case 4 and one in the case 5 . The two oldest ages have too large error margins and therefore fit several cases at the same time, making their classification regarding RSL behavior ambiguous. As mentioned in section "Geological significance of OSL ages in Aeolian deposits", this is an inherent limitation of OSL dating, since the error grows proportionally with the determined age.

There is a clear predominance of stable RSL cases (seven cases out of nine), mainly in gentle decrease but also in tendency of inversion. Five out of these seven cases refer to dunes formed with an RSL similar to the present, in a variation margin of about $3 \mathrm{~m}$, all posterior to the last transgressive maximum (G3). This high representation of G3 dunes is

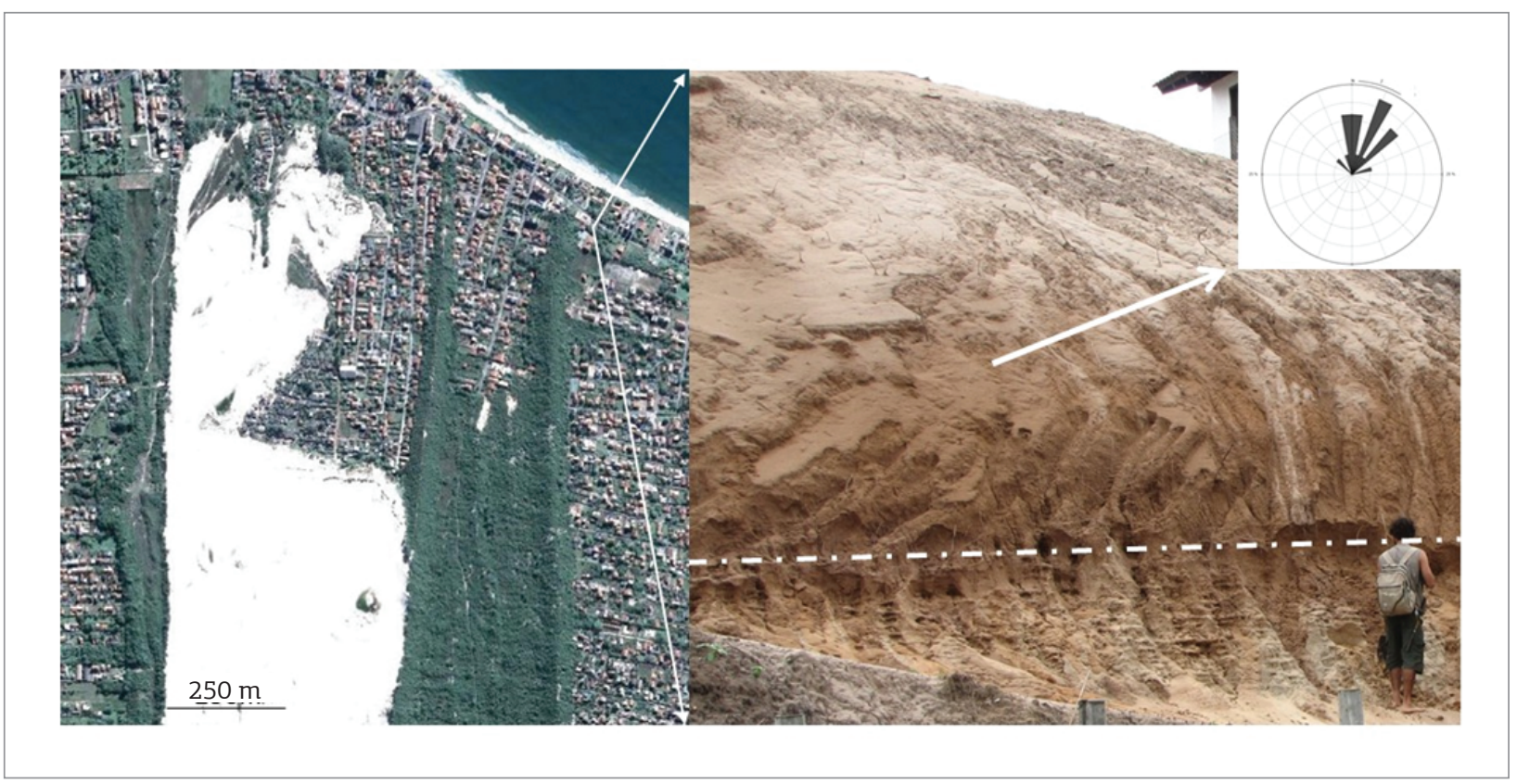

Figure 8. Aerial and outcrop aspects of the main depositional lobe in the Ingleses dunefield. Left: G3 precipitation ridges parallel to the G4 (active) dunefield (image from Google Earth ${ }^{\oplus}$ ). Right: Contact (highlighted by the dashed line) between the Pleistocene marine terrace, with external tabular shape and sub-horizontal pedogenic impregnation layers, and G2, with a wavy top and trough cross stratifications in festoon pattern. Upper right box: circular histogram of cross strata dip directions (18 measurements), indicating average azimuth of $\mathrm{N} 17^{\circ}$. 
surely caused by a sampling bias. Stabilized dunes formed with high RSL, similar to the present, and at coast lines close to the present ones are more or better exposed at the present coastal zone than dunes formed under RSL and at coast line positions very discrepant from the present ones (Giannini 2007, Giannini et al. 2007, Guedes 2012). Their presence can be favored also by a preservation bias, where more recent deposits generally are better preserved than older ones.

Nevertheless, stable RSL conditions are as predominant among the younger ages (G3) as among the oldest ages (G2). So, stable RSL seems to be in fact an effective controlling factor for aeolian dune formation and/or preservation. A point in favor of the possible connection between stable RSL and aeolian supply, defended by Giannini et al. (2001, 2007), is the maintenance of the distance between the forming dunefields and their source areas at the coastline. The stability of this distance would constitute a favorable factor in the formation or maintenance of the active dunefields. The authors' argument is that the stability of the coastline, not assured but favored by a stable RSL, is a necessary condition for the activity of the aeolian system, since wind transport and deposition dilute throughout a wide coastal area,if the coastline varies quickly.

The deposits of the two oldest generations were reached by the sea during the two latest maximum floodings of the Brazilian coast (Giannini 1993). Giannini (2007) and Giannini et al. (2007) considered this as evidence that these generations were formed, at least partially, under a transgressive terminal context (shortly before the maximum inundation). They based this assumption on the premise that, because these paleodunes are close to the present coast, they were generated at similar shorelines and RSL as present. In these authors' model, the two youngest generations, attributed to the regression that followed the maximum Holocene flood, would have still formed in the same high RSL context responsible for the

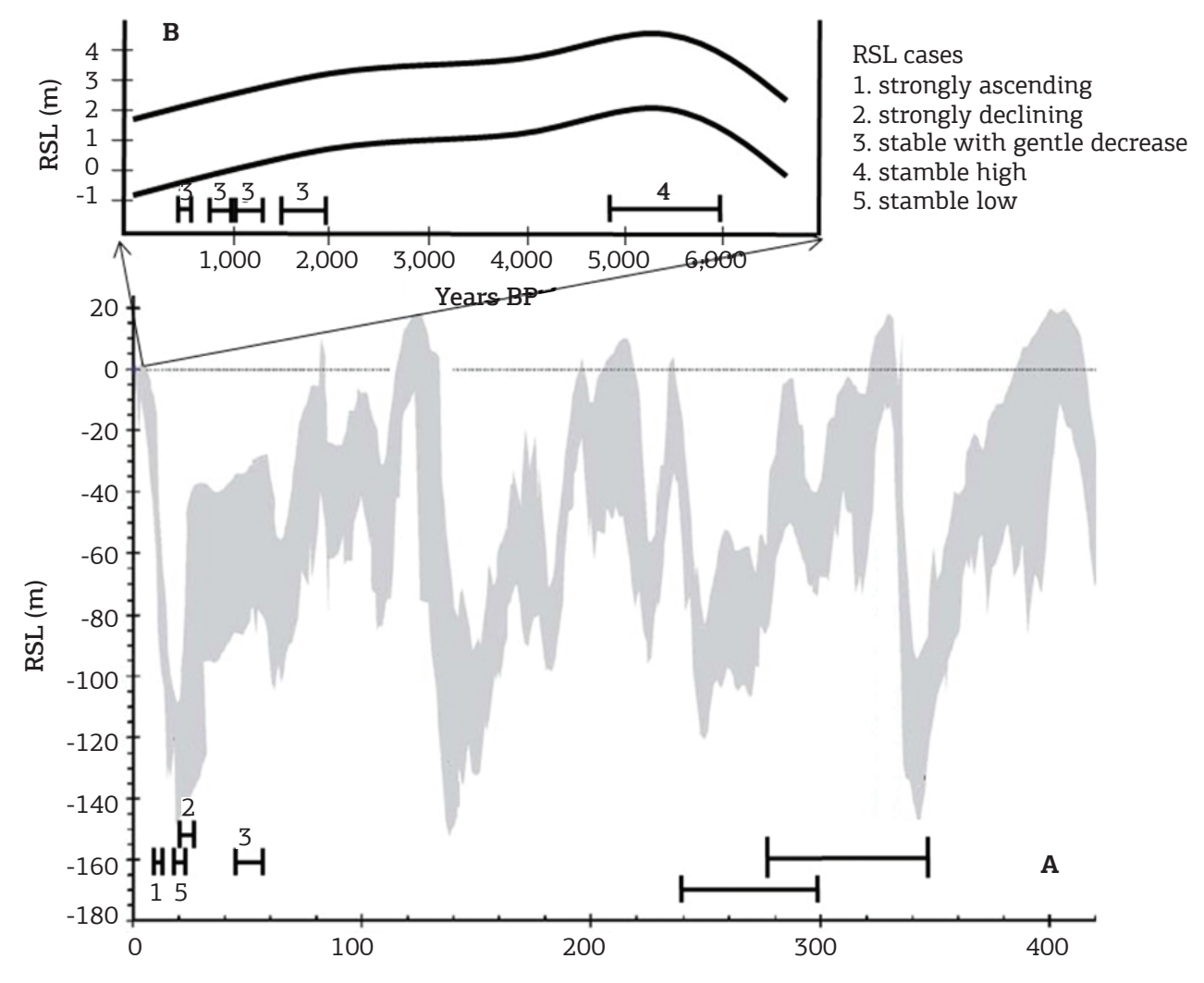

Kilo Years BP

Figure 9. Global (A) adapted from Rabineau et al. 2006) and Brazilian (B) adapted from Angulo et al. 2006) RSL variation envelopes, for the last 400 and 7 ky, respectively. The horizontal bars show the interval comprised by each aeolian sample dated in this paper plus the respective error margin. The numbers above the bars indicate the RSL situations (cases). Samples plotted from oldest to youngest A: GP-G1-90, PM-G1-21, IN-G2-09, PI-G2-74 and IN-G2-07; B: PI-G3-53, JO-G3-40, PI-G3-54, OU-G3-103 and PI-G3-56. 
previous generations, however without reaching such internalization. Following the reasoning of the favorability of the shoreline stability in the formation of dunefields, proposed by Giannini (2007) and Giannini et al. (2007), the stable shoreline periods, during glacial maxima, and therefore with a low RSL, would also be favorable to the development of coastal aeolian systems (Guedes 2012).

However, there is a relative higher difficulty for the formation of coastal dunefields during high sea level, when compared to ones formed during low sea level, which relates to the relative duration of the RSL maintenance. At least during the last million years of Earth history, when Milankovitch orbital cyclicity is dominated by the component of eccentricity variation, with time periods around 100 thousand years, the interglacial periods are shorter in time than the glacial (Ruddimann 2008). Therefore, the high RSL periods are also less durable than the low RSL periods. That means that the profitable time to accumulate big aeolian deposits with coastal source is much shorter under high sea conditions than under low sea level conditions.

Another exception to the model of predominance of aeolian dunes under high RSL relates to the preservation question. Due to the cyclic character of the RSL variations, connected to the succession of glacial and interglacial stages, a dunefield formed under high RSL conditions tends to be, in the passage to a new glacial stage, submitted to a substantial fall of the base level of erosion, due to the lowering of RSL and groundwater. This base level fall would hinder the preservation of its deposits for a long time, i.e., for a time compatible with an eccentricity cycle. Dunefields formed under a high RSL would be more subject to subaerial erosion, mainly because of the subsequent RSL fall (forced regression). On the other hand, the deposits formed during a low RSL could be reworked by the shoreline transgression. Meanwhile, if that transgression is a result of the RSL rise with a high rate, only the superficial aeolian deposits would be reworked, which would considerably increases their preservation potential in geological time (Guedes 2012).

\section{Age distribution in relation to climate variations}

Nine from the 11 dated aeolian dunes have their age distribution analyzed in relation to the more accepted climate variations during the last $120 \mathrm{ky}$ (there are no climatic reconstructions for the period of the two oldest samples). The OSL ages were plotted inside graphics of $\delta^{18} \mathrm{O}$ variation over time, obtained in southern Brazil speleothems (Figs. 10 and 11). In these graphics, the more negative isotope ratio values, connected to the rain amount effect, result from the SAMS intensification and, therefore, they are correlated with greater atmospheric humidity values (Cruz et al. 2006, 2007, 2009). The aeolian ages distribution analysis was made separately in two different timescales. In the first and most embracing, corresponding to only five of the older samples, the ages are all related to climate transition moments, from less to more humid and/or humidity minima followed by humidity maxima (Fig. 10).

Transition periods, with a humidity increase, and consequently with a sand moisture increase, and periods of minimum moisture followed by its quick increase would be favorable to the development and stabilization of aeolian dunes for two main reasons. The first, connected to the dunefield formation, would be the decrease of the vegetation cover, with the resulting encouragement of wind transport (Carter 1990, Hesp \& Thom 1990, Hesp 2000). The second reason, connected to the stabilization of the aeolian dunes, would be a possible reduction of wind intensity with rain increase. Similar effect is observed in the recent stabilization of the central coastal dunes of Santa Catarina (Miot da Silva \& Hesp 2013, Mendes \& Giannini 2015) and medium north of Rio Grande do Sul (Martinho et al. 2010). Weather data from the last century points to the rise of the annual precipitation associated with a decrease of the wind intensity as the main control factor of stabilization observed on the dunefields of the Santa Catarina coast. In this context, the dune stabilization would be supported by the combined effects of:

1. the vegetation grown and/or development of wetlands on the deflation zones;

2. the increase of the transportation threshold due to the sand cohesion induced by the moisture increase; and

3. the decrease of the wind intensity (Mendes \& Giannini 2015).

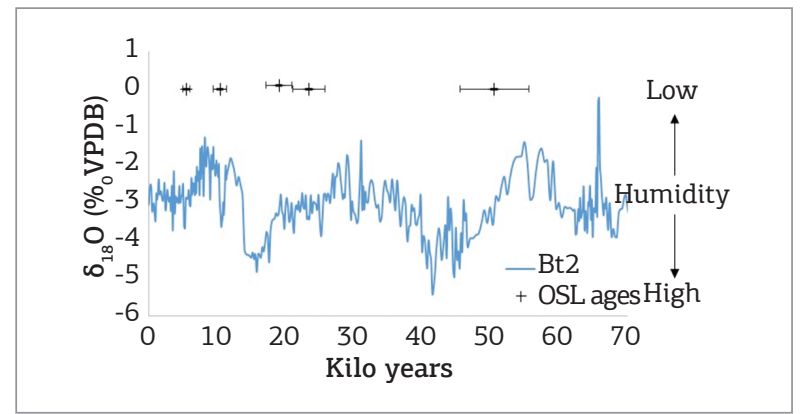

Figure 10. Distribution of the OSL ages for the aeolian deposit samples in relation to the climate variations registered in stalagmites from Botuverá cave (Cruz et al. 2007), sited in Santa Catarina State, about $80 \mathrm{~km}$ west of the study area. Apparently, the samples are placed in moments of curve decline (humidity increase) and/or in its positive peaks (humidity minima), followed by a quick decrease (abrupt humidity augment). 


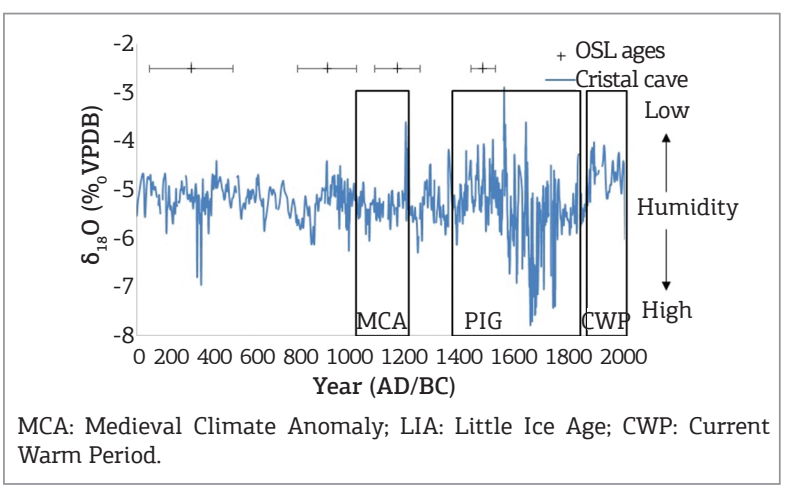

Figure 11. Distribution of the dated samples (ages with error bars) in relation to the high resolution $\delta^{18} \mathrm{O}$ record, from the Cristal Cave (about $300 \mathrm{~km} \mathrm{NNW}$ from study site) (adapted from Vuille et al. 2012).

The second timescale is comprised inside the first one as slight oscillations, representative of the secular climate change. It is observed more easily during the three last millennia, corresponding to G3. The error involved in the dates is from about hundred to tens of years. On this timescale, three of the four youngest OSL ages include falling or negative peaks of humidity, with humidity increase in the end (Fig. 11), a pattern similar to that found in the first timescale (Fig. 10). This way, the mechanism of climate control for the formation and stabilization of dunes inferred from the longer timescale would also act on this shorter timescale. This coincidence implies, as a general rule, that the dunefields would be generated during moments of monsoon weakening and stabilized during its intensification.

Summarizing, in the climate variation context, the dunefields would be preferentially formed during the less humid climate moments, connected to the weakening of the monsoons, and stabilized during the subsequent more humid moments, of monsoon strengthening. Based on the available OSL-SAR ages, this pattern is apparently valid, both on the tens of thousands of years scale, as on the last thousands of years scale, when the peaks of less humidity can be represented, for example, by MCA and CWP (Fig. 11), and on the most humidity ones, by the Bond events and the LIA.

\section{CONCLUSIONS}

Based on the results obtained and discussed in this article, the main conclusions can be summarized as follows:

1. Four aeolian generations are recognizable based on remote sensing, field work and OSL dating. They are correlated with the generations previously defined for the centersouth coast of Santa Catarina and possibly extendable to other coastal regions with aeolian dunefields in Brazil.

2. Based on the OSL ages, it is possible to infer at least three stages of dune formation inside the older generation (G1), which would correspond to high relative sea levels since the Late Pleistocene highstand (120 ky). Therefore, from the chronology point of view, the G1 unit could be divided into three units.

3. The relation between the aeolian generations age distribution and the global curve of RSL variation during the Late Pleistocene allows to suggest that the formation of aeolian dunefields of coastal context is favored by stable RSL, and their preservation is helped by the subsequent increase of RSL. However, RSL clearly is not the only determinant for the formation and preservation of the aeolian coastal dunes, given the evidences of climatic control. The formation of dunefields would be favored by periods of less humidity while their stabilization would occur preferably during the periods of rain intensification, connected to monsoon activity.

\section{ACKNOWLEDGMENTS}

To FAPESP, processes2009/53988-8 and 2009/54232-4; CAPES; and CNPq, process 149544/2010-3.

\section{REFERENCES}

Angulo R., Lessa G.,Souza M. 2006. A critical review of mid- to lateHolocene sea-level fluctuations on the eastern Brazilian coastline. Quaternary Science Reviews, 25(5-6):486-506.

Barbosa L.M. 1997. Campos de dunas costeiras associados à desembocadura do Rio São Francisco (SE/AL). Tese de Doutoramento (inédita), Instituto de Geociência, Universidade Federal da Bahia, Salvador, $202 \mathrm{p}$.

Barbouti A.I. \& Rastin B.C. 1983. A study of the absolute intensity of muons at sea level and under various thicknesses of absorber. Journal of Physics G: Nuclear Physics, 9(12):1577.

Barboza E.G., Dillenburg S.R., Rosa M.L.C.C., Tomazelli L.J., Hesp P.A. 2009. Ground-penetrating Radar Profiles of Two Holocene
Regressive Barriers in Southern Brazil. Journal of Coastal Research, SI 56:579-583.

Barreto A.M.F., Suguio K., Bezerra F.H.R., Tatumi S.H., Yee M., Giannini P.C.F. 2004. Geologia e geomorfologia do quaternário costeiro do estado do Rio Grande do Norte. Geologia USP. Série Científica, 4:1-12.

Barreto A.M.F., Suguio K., Bezerra F.H.R., Tatumi S.H., Yee M., Oliveira P.E. 2002. Datação de dunas costeiras inativas do Estado da Paraíba por métodos de luminescência. In: Congresso Brasileiro de Geologia, 41, João Pessoa, PB, Anais... João Pessoa, SBG, p. 351.

Bigarella J.J. 1975. Lagoa dune fields (State of Santa Catarina, Brazil), a model of eolian and pluvial activity. Boletim Paranaense de notícias, 33:133-167. 
Bigarella J.J., Klein A.H.F., Menezes J.T., Vintém G. 2005. Sub-Tropical Coastal Dunes: Examples from Southern Brazil. Journal of Coastal Research, SI42:113-137.

Carter R.W.G. 1990. The geomorphology of coastal dunes in Ireland. In: Bakker T.W., Jungerius P.D., Klijn J.A. (eds.). Dunes of the European Coasts: Geomorphology -Hydrology - Soils. Germany, Elsevier, p. 31-40.

Claudino-Sales, V. \& Peulvast J.P. 2002. Dunes generations and ponds on the coast of Ceará, North-East Brazil. In: Allison R. (ed.) Applied Geomorphology. London, John Wiley \& Sons, p. 421-440.

Cruz Jr.F.W., Burns S.J., Jercinovic M., Karmann I., Sharp W.D., Vuille M. 2007. Evidence of rainfall variations in Southern Brazil from trace element ratios $(\mathrm{Mg} / \mathrm{Ca}$ and $\mathrm{Sr} / \mathrm{Ca})$ in a Late Pleistocene stalagmite. Geochimica et Cosmochimica Acta, 71(9):2250-2263.

Cruz Jr.F.W., Burns S.J., Karmann I., Sharp W.D., Vuille M. 2006. Reconstruction of regional atmospheric circulation features during the late Pleistocene in subtropical Brazil from oxygen isotope composition of speleothems. Earth and Planetary Science Letters, 248(1-2):495-507.

Cruz Jr. F.W., Vuille M., Burns S.J., Wang X., Cheng H., Werner M., Lawrence Edwards R., Karmann I., Auler A.S., Nguyen H. 2009. Orbitally driven east-west antiphasing of South American precipitation. Nature Geosciences, 2(3):210-214.

Dillenburg S.R., Barboza E.G. 2009. Long- and short term progradation of a regressive barrier in southern Brazil. Journal of Coastal Research, SI 56:599-601.

Dillenburg S.R., Barboza E.G., Hesp P.A., Rosa M.L.C.C., Angulo R.J., Souza M.C., Giannini P.C.F., Sawakuchi A.O. 2014. Discussion: Evidence for a transgressive barrier within a regressive strandplain system: implications for complex response to environmental change, by Hein (2013), Sedimentology 60:469-502. Sedimentology, Amsterdam. Print, 61:2205-2212.

Endo K. 1986. Coastal sand dunes in Japan.In: Proceedings of the Institute of Natural Sciences. Nihon University, n. 21, 37-54.

Garreaud R.D., Vuille M., Compagnucci R., Marengo J. 2009. Presentday South American climate. Palaeogeography, Palaeoclimatology, Palaeoecology, 281(3-4):180-195.

Giannini P.C.F. 1993. Sistemas Deposicionais no Quaternário Costeiro entre Jaguaruna e Imbituba, SC. Tese de Doutoramento (inédita), Instituto de Geociências, Universidade de São Paulo, São Paulo, 2 v., 2 mapas, $439 \mathrm{p}$.

Giannini P.C.F. 2002. Complexo lagunar centro-sul catarinense, valioso patrimônio sedimentológico, arqueológico e histórico. In: Sítios Geológicos e Paleontológicos do Brasil, n.75, pp.213-222.

Giannini P.C.F. 2007. Sistemas deposicionais eólicos no Quaternário costeiro do Brasil. Tese de Livre-Docência (inédita), Instituto de Geociências, Universidade de São Paulo, São Paulo, 205p.

Giannini P.C.F. \& Suguio K. 1994. Diferenciação entre gerações de depósitos eólicos quaternários na costa centro-sul de Santa Catarina. In: Congresso Brasileiro de Geologia, 38, Balneário Camboriú, SC. Resumos Expandidos... Balneário Camboriú, SBG. p.402-403.

Giannini P.C.F., Sawakuchi A.O., Martinho C.T. 2001. A estratigrafia de seqüências na evolução das dunas costeiras de Santa Catarina, sul do Brasil. In: Congresso do Quaternário dos Países de Língua Ibérica, Lisboa, Portugal. Actas...pp.117-120.

Giannini P.C.F., Assine M.L., Barbosa L., Barreto A.M.F., Carvalho A.M., Claudino-sales V., Maia L.P., Martinho C.T., Peulvast J.P., Sawakuchi A.O., Tomazelli L.J. 2005. Dunas e paleodunas eólicas costeiras e interiores. In: Souza C.R.G., Suguio K., Oliveira P.E., Oliveira. A.M. (eds.) Quaternário do Brasil (capítulo 11). Abequa, ANP, FAPESP, IG, UnG. Ribeirão Preto, SP, Holos Editora, p.235-257.
Giannini P.C.F., Sawakuchi A.O., Martinho C.T., Tatumi S.H. 2007. Eolian depositional episodes controlled by Late Quaternary relative sea level changes on the Imbituba-Laguna coastal zone (southern Brazil). Marine Geology, 237:143-168.

Guedes C.C.F., Giannini P.C.F., Sawakuchi A.O., Dewitt R., Nascimento D.R., Aguiar V.A.P., Rossi M.G. 2011. Determination of controls on Holocene barrier progradation through application of OSL dating: The Ilha Comprida Barrier example, Southeastern Brazil. Marine Geology, 285:1-16

Guedes C.C.F. 2012. Cronologia e sedimentologia dos depósitos eólicos quaternários do leste maranhense. Tese de Doutoramento, Instituto de Geociências, Universidade de São Paulo, 115p. + 7 anexos.

Haylock M.R., Peterson T.C., Alves L.M., Ambrizzi T., Anunciação Y.M.T., Baez J.,

Barros V.R., Berlato M.A., Bidegain M., Coronel G., Corradi V., Garcia V.J.,

Grimm A.M., Karoly D., Marengo J.A., Marino M.B., Moncunill D.F., Nechet D., Quintana J., Rebello E., Rusticucci M., Santos J.L., Trebejo I., Vincent L.A. 2006. Trends in Total and Extreme South American Rainfall in 1960-2000 and Links with Sea Surface Temperature. Journal of Climate, 19(8):1490-1512.

Hein C.J., Fitzgerald D.M., Cleary W.J., Albernaz M.B., De Menezes J.T., Klein A.H.F. 2013. Evidence for a transgressive barrier within a regressive strandplain system: Implications for complex coastal response to environmental change. Sedimentology, 60(2):469-502.

Hein C.J., Fitzgerald D.M., Klein A.H.D.F., Albernaz M.B., Menezes J.T., Cleary W.J. 2014. Reply to the Discussion by Dillenburg et al. on "Evidence for a transgressive barrier within a regressive strandplain system: implications for complex response to environmental change", by Hein et al. (2013), Sedimentology 60:469-502. Sedimentology, 61(7):2213-2217.

Heinrich H. 1988. Origin and consequences of cyclic ice rafting in the northwest Atlantic Ocean during the past 130,000 years. Quaternary Research, 29:142-152.

Hesp P., Abreu de Castilhos J., Miot da Silva G., Dillenburg S., Martinho C.T., Aguiar D., Antunes G. 2007. Regional wind fields and dunefield migration, southern Brazil. Earth Surface Processes and Landforms, 32(4):561-573.

Hesp P.A. \& Thom B.G. 1990. Geomorphology and evolution of active transgressive dunefields. In: Nordstrom K.F., Psuty N.P., Carter R.W.G. (eds). Coastal Dunes: Form and Process. Chichester, John Wiley \& Sons Ltd.

Hesp P.A. 2000. Coastal Sand Dunes. Form and Function. Massey, Massey University, 28p.(CDNV Technical Bulletin, 4).

Hesp P.A., Giannini P.C.F., Martinho C.T., Miot da Silva M.G., Asp Neto N.E. 2009. The Holocene barrier system of the Santa Catarina coast, Southern Brazil. In: Dillenburg S.R. \& HespP.A. (ed.) Geology and Geomorphology of Holocene Coastal Barriers of Brazil. Lecture Notes in Earth Sciences.Berlin, Heidelberg, Springer, p.93-134.

Lees B. 2006. Timing and formation of coastal dunes in northern and eastern Australia.Journal of Coastal Research, 22(1):78-89

Loope W.L. \& Arbogast A.F. 2000. Dominance of an 150-year cycle of sand-supply change in Late Holocene dune-building along the eastern shore of Lake Michigan. Quaternary Research, 54:414-422.

Martin L., Suguio K., Flexor J.N., Azevedo A.E.G. 1988. Mapa Geológico do Quaternário costeiro dos estados do Paraná e Santa Catarina. Brasília, DNPM, 40 p., 2 mapas (Série Geologia 28, Seção Geologia Básica 18).

Martin L.,Flexor J.L.,Suguio K. 1995 . Vibrotestemunhador leve: construção, utilização e potencialidades. Revista IG-USP, 16(1/2):59-66. 
Martinho C.T. \& Giannini P.C.F. 2001. Petrografia e microscopia eletrônica de varredura de diferentes gerações de paleodunas eólicas quaternárias do morro de Santa Marta, município de Laguna, SC. Pesquisas, 28(2):53-66

Martinho C.T., Hesp P.A., Dillenburg S.R.2010. Morphological and temporal variations of transgressive dunefields of the northern and mid-littoral Rio Grande do Sul coast, southern Brazil. Geomorphology, 117:14-32

Martinho C.T., Giannini P.C.F., Sawakuchi A.O., Hesp P.A. 2006. Morphological and depositional facies of transgressive dunefields of the Imbituba-Jaguaruna region, Santa Catarina State, Southern Brazil. Journal of Coastal Research, 39:673-677.

Mendes V.R. \& Giannini P.C.F. 2015. Coastal dunefields of south Brazil as a record of climatic changes in the South American monsoon system. Geomorphology. 2015;246:22-34.

Miot da Silva G. 2006. Orientação da linha de costa e dinâmica dos sistemas praia duna: praia de Moçambique, Florianópolis, SC. Tese de Doutorado, Universidade Federal do Rio Grande do Sul, Porto Alegre.

Miot da Silva G. \& Hesp P.A. 2013. Increasing rainfall, decreasing winds, and historical changes in Santa Catarina dunefields, southern Brazil.Earth Surface Process and Landforms, 38:1036-1045.

Murray A.S. \& Wintle A.G. 2000. Luminescence dating of quartz using an improved single-aliquot regenerative-dose protocol. Radiation Measurement, 32:57-73.

Prescott J.R. \& Stephan L.G. 1982.The contribution of cosmic radiation to the environmental dose for thermoluminescence dating. In: Proceedings of the Second Specialist Seminar on Thermoluminescence Dating 6, Council of Europe, Strasbourg,p. 17-25.

Pye K. 1983. Formation and history of Queensland coastal dunes. Z. Geomorphol., suppl-bd. 45:175-204.

Rabineau, M., Berná, S., Olivet, J.L., Aslanian, D., Guillocheau, F., Joseph, P. 2006. Paleo sea levels reconsidered from direct observation of paleoshoreline position during Glacial Maxima (for the last 500,000 yr). Earth and Planetary Science Letters, 252, 119-137.
Ruddiman W.F. 2008. Earth's Climate. Past and Future. 2ed., W.E. Freeman, $465 \mathrm{p}$

Sawakuchi A.O. 2003. Sistemas Deposicionais Eólicos na Costa Centro-Sul Catarinense: Relações com o Nivel do Mar. Dissertação de Mestrado (inédito), Programa de Pós-Graduação em Geologia Sedimentar, IG-USP, 86 p.

Sawakuchi A.O., Kalchgruber R., Giannini P.C.F., Nascimento D.R., Guedes C.C.F., Umisedo N. 2008. The development of blowouts and foredunes in the Ilha Comprida barrier (Southeastern Brazil): the influence of Late Holocene climate changes on coastal sedimentation. Quaternary Science Reviews, 27:2076-2090.

Short A.D. 1988. Wave, beach, foredune, and mobile dune interactions in the Southern Australia. Journal of Coastal Research, SI3:05-09.

Stokes S., Kocurek G., Pye K., Winspear N.R. 1997. New evidence for the timing of aeolian sand supply to the Algodones dunefield and East Mesa area, southeastern California, USA. Palaeogeography, Palaeoclimatology, Palaeoecology, 128:63-75.

Vera C.S., Vigliarolo P.K., Berbery E.H. 2002. Cold season synopticscale waves over subtropical South America. Monthly Weather Review,130:684-699.

Vuille M., Burns S.J., Taylor B.L., Cruz F.W., Bird B.W., Abbott M.B., Kanner L.C., Cheng H., \& Novello V.F. 2012. A review of the South American monsoon history as recorded in stable isotopic proxies over the past two millennia. Climate of the Past, 8(4):1309-1321.

Wang X., Auler A.S., Edwards R.L., Cheng H., Ito E., Solheid M. 2006. Interhemispheric anti-phasing of rainfall during the last glacial period. Quaternary Science Reviews, 25:3391-3403.

Wintle A.G. \& Murray A.S. 2006. A review of quartz optically stimulated luminescence characteristics and their relevance in single-aliquot regeneration dating protocols. Radiation Measurements, 41:369-391.

Zular A. 2011. Sedimentologia e cronologia por luminescência da Ilha de São Francisco do Sul (SC): considerações sobre a evolução holocênica de barreiras arenosas da costa sul e sudeste do Brasil. Dissertação de Mestrado, Instituto de Geociências, Universidade de São Paulo, São Paulo. 95p.

Arquivo digital disponível on-line no site www.sbgeo.org.br 